\title{
Population Density and Habitat Characteristics of Nipa Fruticans in Degraded Mangrove Ecosystem (Case Study in Mahakam Delta, East Kalimantan)
}

\author{
Nurul Silva Lestari ${ }^{1 *}$ and R. Fatmi Noor'an ${ }^{2)}$ \\ ${ }^{1}$ Center for Research and Development of Socio-Economic Policy and Climate Change \\ Jl. Gunung Batu No 5 Bogor, 16118 \\ ${ }^{2}$ Dipterocarp Forest Ecosystem Research and Development Center
}

Jl. AW. Syahrani No. 68 Samarinda, 75119

\begin{abstract}
Mahakam Delta is one of the largest mangrove ecosystem areas in East Kalimantan, which is dominated by nipa (Nypa fruticans). This paper investigates the population density of nipa and measures habitat characteristics in the area, which represents the condition of mangrove ecosystem that has received heavy pressures as a result of the increase in human activities. A total of 30 plots, size of $100 \mathrm{~m}^{2}$ each plot, were sampled from six locations in the study site. In each plot, the number of individual, stalk, leaves, fruit and flower of nipa was recorded. Nipa zone adjacent to active ponds area had the density of 106 individual/ha with 913 stalks ha $^{-1}$. The leaf density was 336 leaves ha ${ }^{-1}$, fruit density was 12 fruits ha $^{-1}$ and flower density was 12 flowers/ha. Furthermore, nipa density in locations faraway from active ponds area was 74 individual/ha with 861 stalks/ha. While the leaf density was 239 leaves/ha, fruit density in this area was 2 fruits/ha and flower density was 9 flowers/ha. Result also showed that nipa habitat in study site is characterized by high turbidity and low salinity. Among other parameters, tidal level has strongest correlation to nipa population density. This study can also be considered as a preliminary assessment to develop mangrove ecosystem rehabilitation action plans in Mahakam Delta and to consider the potential use of nipa as an alternative source of livelihood for local communities living in the vicinity of the Mahakam Delta area.
\end{abstract}

Keywords: mangrove, nipa, Mahakam Delta

\section{INTRODUCTION}

Many studies have reported that mangrove forest plays various ecological functions, such as biodiversity conservation and as coastline protection from erosion (Dutrieux et al., 2014). In addition, mangrove ecosystem is also essential for providing resources for the livelihoods of local communities. Mahakam Delta has become a notable mangrove ecosystem in East Kalimantan due to its ecological, social and economic importance. Mangrove forests in Mahakam Delta function as feeding source as well as spawning

Correspondence: Nurul Silva Lestari, Center for Research and Development of Socio-Economic Policy and Climate Change

Jl. Gunung Batu No 5 Bogor (16118), Indonesia.

E-mail: nurulsilva@gmail.com and nursery grounds for aquatic organisms, which become a primary source of local communities' livelihoods (Dutrieux et al., 2014; Sidik, 2010). Zain et al. (2014) also noted that mangrove forest in Mahakam Delta has high economic value for communities, from both direct use and indirect use values.

Mahakam Delta has been a subject to anthropological disturbance for several last decades. One of the biggest threats in these areas is the conversion of mangrove forests into ponds. Dutrieux et al. (2014) reported that $85 \%$ of mangrove ecosystem in Mahakam Delta was damaged and replaced by aquaculture ponds by 2001. It is therefore important to measure mangrove habitat characteristics to find out the 
impact of mangrove conversion to environmental conditions which may affect ecosystem balance in the area.

Even though mangrove ecosystem in Mahakam Delta has been widely recognized, current information on vegetation composition of mangrove ecosystem in these areas based on field measurement remains limited. Most studies mainly focused on the change of mangrove area over time (Dutrieux et al., 2014; Sidik, 2010), conflicts related to natural resources utilization and related stakeholders in this area (Dutrieux et al., 2014; Sidik, 2010), economic value of the area (Susilo et al. 2017; Wahyuni et al. 2014) and carbon dynamics of mangrove conversion (Arifanti et al., 2018). This gap of information needs to be filled in order to provide more comprehensive information about the impacts of human activities that have been occurring in this area for a long period of time. As a predominant mangrove species in Mahakam Delta, nipa population density has been highly affected by the disturbances. Moreover, by understanding the population density of nipa, potential use of nontimber forest product in this area could be promoted. Several studies point out that non timber forest products of mangrove plant species can contribute in supporting sustainable livelihoods and providing food source for local communities in various locations (Arifanti et al., 2018; Santoso et al., 2005; Situmorang \& Barus, 2015)
Given that aquaculture ponds still become a main preference for communities' livelihood, forest management should also consider the utilization of mangrove forest resources that can bring economic benefit to the communities other than aquaculture ponds that lead to mangrove forest conversion. This study aimed to provide up to date information on population density of nipa and measure habitat characteristics of the area as a representative of disturbed mangrove forest in Mahakam Delta. The result of this study is also expected to be used as a consideration in Mahakam Delta management plan development, which include the involvement of local communities in conserving mangrove ecosystem without neglecting the livelihood sustainability of local communities.

\section{METHODS}

\section{Study Site}

This research was conducted in Barat Muara Kaeli Research and Education Forest, Kutai Kartanegara Regency, East Kalimantan, which located between 0'29'34" - 0'23'25' south latitude and $117^{\circ} 19^{\prime} 40^{\prime \prime}$ - $117^{\circ} 25^{\prime} 32^{\prime \prime}$ east longitude. This forest area is part of Mahakam Delta mangrove ecosystem. Administratively, the forest area is situated in two districts, Anggana and Muara Badak. Average annual rainfall in this area is about $187.75 \mathrm{~mm}$ in the period of 2010 2014. 


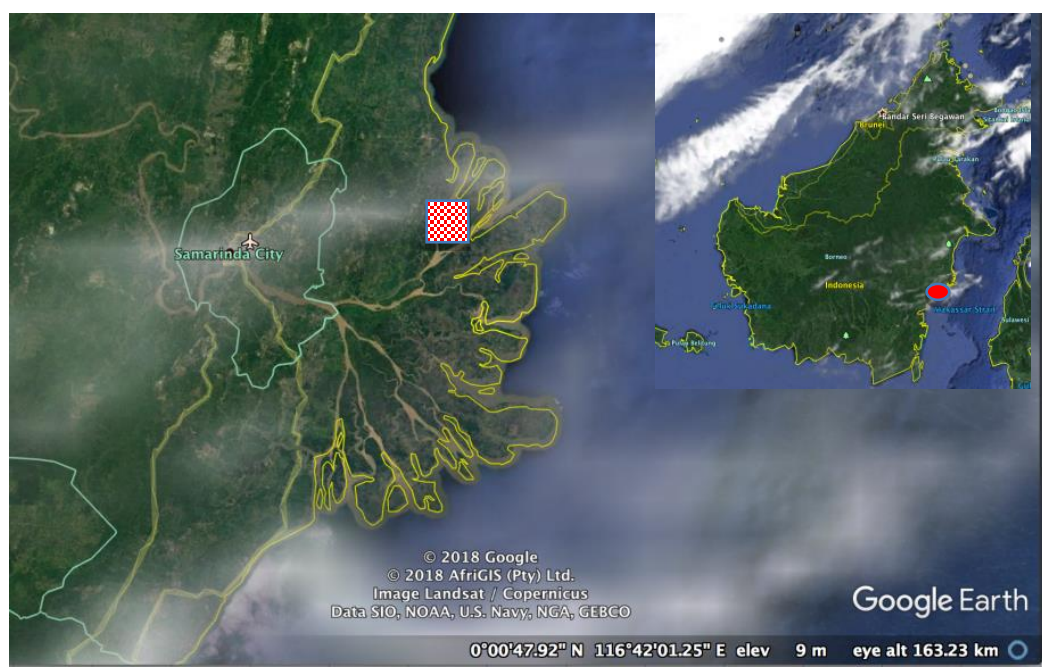

Figure 1. Study Area

\section{Data collection}

Data was collected in six points in which each point consists of five plots size of $10 \times 10 \mathrm{~m}^{2}$. We also divided sample point in Nypa fruticans zone into two categories, three points located adjacent to active ponds, while the other three points were far away from active ponds. We classified the location based on the assumption that the ones which adjacent to active ponds are more likely to be exposed by human activities to find out whether this affect nipa community.

Table 1. Site classification

\begin{tabular}{ll}
\hline \multicolumn{1}{c}{ Location } & \multicolumn{1}{c}{ Site characteristics } \\
\hline T1 & Nypa fruticans zone - no active ponds \\
T2 & Nypa fruticans zone - adjacent to active ponds \\
T3 & Nypa fruticans zone - adjacent to active ponds \\
T4 & Nypa fruticans zone - adjacent to active ponds \\
T5 & Nypa fruticans zone - no active ponds \\
T6 & Nypa fruticans zone - no active ponds \\
\hline
\end{tabular}

In each plot, we measured the number of individual as well as the number of stalks, flower and fruit. We also collected data on environmental conditions in each plot, which consists of water quality, temperatures, humidity, tidal level, and $\mathrm{pH}$ soil.

\section{Data Analysis}

The data was further analyzed to find out species density using the following equations:

Species density $=\frac{\text { the number of individual }}{\text { total area of sample plot }}$

(1) 
Meanwhile, habitat characteristics data was Mulawarman University. Methods used in water quality assessment are as follows. further analyzed in Water Quality Laboratory,

Table 2. Methods used in water quality assessment

\begin{tabular}{lll}
\hline & Parameter & \multicolumn{1}{c}{ Method } \\
\hline \multirow{3}{*}{ Chemical } & $\mathrm{pH}$ & SNI 06.6989.11-2004 \\
& DO & SNI 06.69889.14-2004 \\
& Total-P & SNI 06.6989.31-2005 \\
\hline \multirow{3}{*}{ Physical } & Turbidity & Turbiditymeter \\
& Redox potential & Potentiometry \\
& Salinity & Hand-refractrometry \\
Inorganic & BOD-5 & APHA,5210-B, 22 \\
chemical & $\mathrm{COD}$ & SNI 06.6989.73-2009 \\
& $\mathrm{NO}_{3}-\mathrm{N}$ & SNI 19-6964.7-2003 \\
\hline
\end{tabular}

SNI: Indonesian National Standard

In addition, t-test was performed to find out if there is any significance difference on the number of individual, stalk, leaves, fruit and flower of nipa between location adjacent to active ponds and location with no active ponds nearby.

\section{RESULTS AND DISCUSSION}

\section{Nipa Population Density}

Nipa zone is the largest area compared to other vegetation zone in Mahakam Delta. According to Dutrieux et al. (2014), the nipa area accounted for $551 \mathrm{~km}^{2}$ or $53.9 \%$ of the total mangrove ecosystem in Mahakam Delta. The result of this study showed that nipa density in area adjacent to ponds was about 106 individualsha ${ }^{-1}$, higher than in area with no ponds, which was 74 individuals $\mathrm{ha}^{-1}$. Similar pattern also occurred in the density of stalk, leaf and fruit in which stalk density in pond adjacent area was 913 stalks ha ${ }^{-1}$, leaf density was 336 leavesha $^{-1}$ and fruit density was 12 fruitsha $^{-1}$. Meanwhile in no ponds area, the density of stalk, leaf and fruit were 861 stalks ha $^{-1}, 239$ leavesha $^{-1}$ and 2 fruitsha $^{-1}$, respectively. Concurrently, the number of nipa flower in no ponds area was 12 flowers $\mathrm{ha}^{-1}$, higher than in adjacent pond area, which was 9 flowers $\mathrm{ha}^{-1}$. 


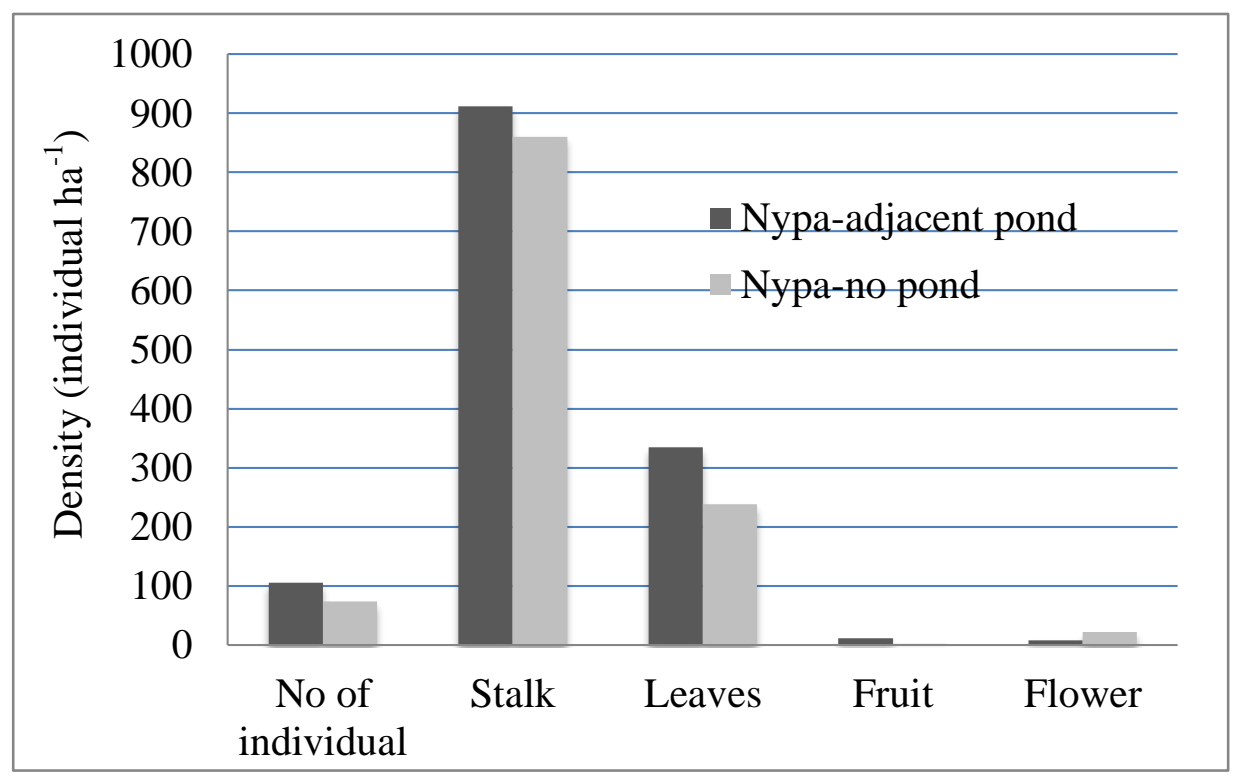

Figure 1. Study Area

However, there were no significant differences between area adjacent to ponds and nipa area with no pondson the number of individual $(\mathrm{p}$-value $=0.09925)$, stalk $(\mathrm{p}$-value $=$ $0.7861)$, leaves $(\mathrm{p}$-value $=0.2375)$, fruit $(\mathrm{p}$-value $=0.1035)$ and flower $p$-value $=0.1777$.

The number of stalk and leaves of nipa can be used to calculate nipa growth in certain period of time. Moreover, this data can also be used to estimate the age of nipa by collecting time series data. Age estimation is determined by multiplying the number of leaves occurred and time interval on leaf growth. In addition, the number of flower and fruit can also indicate the production of nipa flower and fruit (Rozainah \& Aslezaeim, 2010). Result also showed that population density of nipa located nearby active ponds was higher than those in the area where no ponds were operated. This result could also show that human activities in this area is more likely to increase nipa abundance. Human activities may lead to waste deposit in mangrove swamp that could accumulate and alter swampy soil. This condition is favorable for nipa growth (Wang et al., 2016).

Nipa is considered as 'single stand' species. Nipa also has higher population density compared to other mangrove species. This is because nipa grows in clusters and tends to create large colonies (Tsuji et al., 2011). This species is also considered to threaten other mangrove species and might decline biodiversity in mangrove ecosystem. However, further research is required to find out the effect of nipa occurrence on other mangrove species (Middeljans, 2014).

\section{Habitat Characteristics}

Environmental conditions varied during measurement in the field. Water temperature ranged between $27-29.44^{\circ} \mathrm{C}$, while ambient temperature between $27.26-32.84^{\circ} \mathrm{C}$. The 
differences in temperatures were influenced by area openness in which more open areas tend to have higher temperature. Moreover, tidal level at study sites also varied, in which the lowest one was in $\mathrm{T} 1$, while the other sites had almost similar tidal level (Table 4).

Table 4. Environmental conditions at study site

\begin{tabular}{lrrrr}
\hline Point & \multicolumn{1}{c}{ Water } & \multicolumn{2}{c}{ Ambient } \\
temperature $\left({ }^{\circ} \mathrm{C}\right)$ & temperature $\left({ }^{\circ} \mathrm{C}\right)$ & Humidity & Tidal level $(\mathrm{cm})$ \\
\hline T1 & 28.56 & 30.44 & 70.4 & 72.8 \\
T5 & 27 & 30.04 & 71 & 105.4 \\
T6 & 28.66 & 32.84 & 61.6 & 93.8 \\
T2 & 28.12 & 29.76 & 72 & 97.6 \\
T3 & 27.44 & 31.28 & 61.8 & 97.8 \\
T4 & 27.14 & 27.26 & 79.2 & 101.2 \\
\hline
\end{tabular}

Meanwhile, the results of laboratory analysis showed that $\mathrm{pH}$ in $\mathrm{T} 1, \mathrm{~T} 2$ and $\mathrm{T} 3$ were above 7 , whilst the other locations had $\mathrm{pH}$ lower than 7 . DO in the study sites were almost similar in $\mathrm{T} 1$, $\mathrm{T} 2$, T4, T5 and T6 but significantly lower in T4. Moreover, total phosphorus was quite similar in T1, T3 and T5, while in T2, T4 and T6 were less than 0.1. Turbidity was higher in T3, T4 and T5.
Redox potential values were negative in $\mathrm{T} 1$ and T2. In terms of salinity, all locations had similar salinity values, except for T4, which had highest salinity. In regard to inorganic chemical properties of water in the study site, both BOD and $\mathrm{NO}_{3}-\mathrm{N}$ had almost similar pattern in all locations, while for COD, the lowest was in T5 and the highest was in T4 (Table 5).

Table 5. Water quality at study site

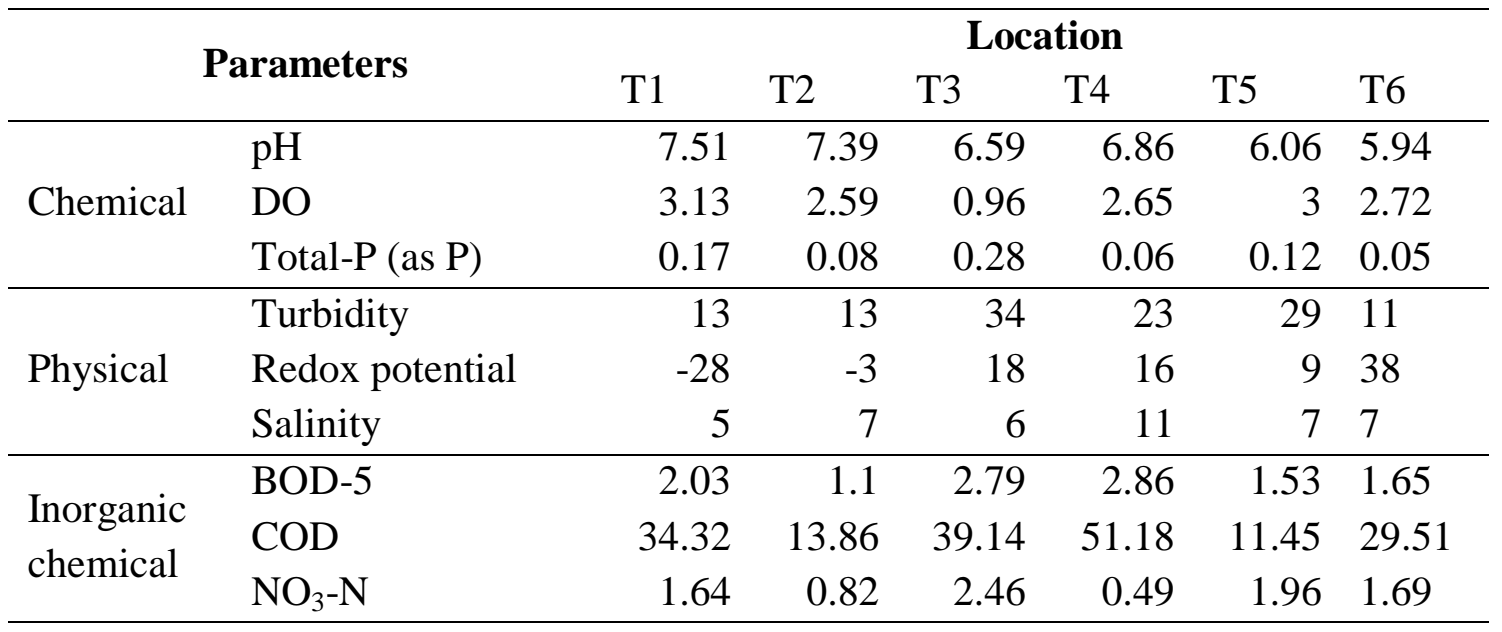

Journal of Wetlands Environmental Management 
The result also indicates that tidal level is significantly correlated with the population density of Nypa fruticans $(\mathrm{r}=0.778)$, while the other parameters have weak correlation with nipa density. Nipa is categorized as fast growing species and commonly found along riverside (Middeljans, 2014). Therefore, this species is also influenced by tidal level. When tidal level is high, nipa would be inundated by salt water, and it would be replaced by freshwater in low tidal level (Rozainah \& Aslezaeim, 2010). Turbidity in all locations in study site was high, while the salinity was low. This confirms the result of other study which mentioned that nipa is more likely to be found in low salinity water (Zakari et al., 2017).

In terms of habitat characteristics, several water quality parameter in this study exceeded water quality standard according to Ministry of Environment (2004). This indicates that this forest area could not properly provide suitable habitat for aquatic fauna. A factor that influences water quality is the conversion of mangrove forest into other land use (Gandaseca et al., 2016). Dutrieux et al. (2014) reported that $85 \%$ of the total mangrove area in Mahakam Delta has been converted into pond in the period of 19802001. This contributes to water quality degradation in Barat Muara Kaeli research and education forest.

\section{Implication for Mangrove Ecosystem Management in Mahakam Delta}

Not only decreasing the area, anthropogenic mangrove ecosystem disturbance also influenced the population density of mangrove species. Compared to undisturbed or low level of disturbance areas, the population density of $\mathrm{Nypa}$ fruticans in the study area tended to be

Journal of Wetlands Environmental Management

Vol 7, No 1 (2019) 50 - 59

http://dx.doi.org/10.20527/jwem.v7.v1.193 significantly lower (Ashton and Macintosh, 2002; Kasawani et al., 2007; Middeljans, 2014; Robertson et al., 1991). These studies found that in undisturbed areas, mean density of seedlings of mangrove species was 9389 \pm 11.8 individual ha ${ }^{-1}$, while nipa has a very high density with 443114800 palmsha $^{-1}$. This difference is related to habitat conditions that affect the occurrence of the mangrove species. Management intervention is required to improve habitat quality by restricting ponds expansion. Furthermore, it is also important to rehabilitate degraded mangrove area by planting, particularly in the riverbank areas as well as building collaboration with other stakeholders working in Mahakam Delta to develop integrated action plans in order to prevent more severe damages.

As mentioned earlier, the provision of alternative livelihoods for local communities is necessary to reduce the extension of pond areas. nipa is one of mangrove species which has high potential economic benefit. Santoso et al. (2005) noted that nipa can be utilized for salt mate 55 substitute, roof, sugar and other food materials. Moreover, nipa in Mahakam Delta also has high potential in producing bio-ethanol (Arindya, 2014). Given the potential of these mangrove species in the study area and also supported by appropriate rehabilitation measures, there is an opportunity to promote the utilization of nontimber forest resources from nipa and Sonneratia alba. However,this needs to be incorporated into management plan of Mahakam Delta. The mangrove ecosystem of Mahakam Delta is now under the management of Forest Management Unit Mahakam Delta (KPH Delta Mahakam). Not only considering the importance of Nypa fruticans for ecological balance of the ecosystem, management plan should also take into account 
the potential benefits of these species as a livelihood alternative for local communities living surrounding the forest area. They can also be involved in forest management to reduce mangrove forest conversion without neglecting their economic necessities. In the new paradigm of forest management in Indonesia, FMU is expected to be able to be self-funded and generate income through sustainable forest resources utilization (KLHK, 2016).

\section{CONCLUSION}

Mangrove ecosystem in Mahakam Delta was dominated by Nypa fruticans. Based on this study, the density population of nipa was 74 individuha $^{-1}$ in the area with no active ponds and 106 individual/ha in the area adjacent to active ponds. These results were considered lower than population density of the same species in other areas where the level of disturbances was not as massive as in Mahakam Delta. Although there was no difference in population density between area adjacent to ponds and area with no ponds nearby, the result might indicates that the damage of mangrove habitat in particular areas in Mahakam Delta could affect the entire areas. Habitat characteristics in the study site was regarded to be suitable for Nypa fruticans in which tidal level has strongest correlation with population density of species compared to other variables but results of water quality analysis showed that the environmental condition in this area could not properly support sustainable habitat for aquatic fauna. In addition, given to the potential economic benefit of Nypa fruticans, Forest Management Unit of Mahakam Delta should also promote the sustainable utilization of this species for economic empowerment program for local community to be incorporated into mangrove ecosystem management in this area.

\section{ACKNOWLEDGEMENTS}

We would like to thank A. Rojikin, Edy, Ahmad, and Pak Sire for helping us in data collection. This research was funded by Dipterocarp Forest Ecosystem Research and Development Agency Annual Budget 2016.

\section{REFERENCES}

Arifanti, V. B., Kauffman, J. B., Hadriyanto, D., Murdiyarso, D., \& Diana, R., 2018. Carbon dynamics and land use carbon footprints in mangrove-converted aquaculture: The case of the Mahakam Delta, Indonesia. For. Ecol. Manag. 432(September). https://doi.org/10.1016/j.foreco.2018.08.047

Arindya, Radita, 2014. Nipah (Nypa fruticans) Utilization for Bio-ethanol at Delta Mahakam. Sch. J. Sci. Res. Essay 3, 83-86.

Ashton, E.C., Macintosh, D.J., 2002. Preliminary assessment of the plant diversity and community ecology of the Sematan mangrove forest, Sarawak, Malaysia. For. Ecol. Manag. 166, 111-129. https://doi.org/10.1016/S03781127(01)00673 $-9$

Dutrieux, E., Proisy, C., Fromard, F., Walcker, R., Liman, M., Pawlowski, F., Ferdiansyah, H., Ponthieux, O., 2014. Mangrove restoration in the vicinity of oil and gas facilities: Lessons learned from a large scale project. Soc. Pet. Eng. - SPE Int. Conf. Health Saf. Environ. 2014 Journey Contin. 2, 1103-1120. https://doi.org/10.1007/s11273011-9244-0 
Gandaseca, S., Wahab, N.L.A., Pazi, A.M.M., Rosli, N., Zaki, P.H., 2016. Comparison of Water Quality Status of Disturbed and Undisturbed Mangrove Forest at Awat-Awat Lawas Sarawak. Open J. For. 06, 14-18. https://doi.org/10.4236/ojf.2016.61002

Kasawani, I., Kamaruzaman, J., Nurun-Nadhirah, M. I., 2007. Biological diversity assessment of Tok Bali mangrove forest, Kelantan, Malaysia. WSEAS Trans. Environ. Dev. 3, 37-44.

KLHK, 2016. Panduan Pola Pengelolaan Keuangan Badan Layanan Umum Daerah Menuju Kemandirian KPH, 2nd ed. Kementerian Lingkungan Hidup dan Kehutanan, Jakarta.

Middeljans, M. J., 2014. The species composition of the mangrove forest along the Abatan River in Lincod, Maribojoc , Bohol, Philippines and the mangrove forest structure and its regeneration status between managed and unmanaged Nipa palm ( Nypa fruticans Wurmb ). Van Hall Larenstein University of Applied Sciences, The Netherlands.

Middeljans, M.J., 2014. The species composition of the mangrove forest along the Abatan River in Lincod, Maribojoc, Bohol, Philippines and the mangrove forest structure and its regeneration status between managed and unmanaged Nipa palm ( Nypa fruticans Wurmb ) The species co. Van Hall Larenstein Univ. Appl. Sci. Neth. 1-38.

Robertson, A. I., Daniel, P. A., Dixon, P., 1991. Mangrove forest structure and productivity in the fly river estuary, Papua New Guinea. Mar. Biol. 111, 147-155.

Journal of Wetlands Environmental Management Vol 7, No 1 (2019) 50 - 59 http://dx.doi.org/10.20527/jwem.v7.v1.193
Rozainah, M. Z., Aslezaeim, N., 2010. A demographic study of a mangrove palm, Nypa fruticans. Sci. Res. Essays 5, 38963902.

Santoso, N., Nurcahya, B. C., Siregar, A. F., Farida, I., 2005. Resep Makanan Berbahan Baku Mangrove. Lembaga Pengkajian dan Pengambangan Mangrove.

Sidik, A.S., 2010. the Changes of Mangrove Ecosystem in Mahakam Delta, Indonesia : a Complex Social- Environmental Pattern of Linkages in Resources Utilization 1. Borneo Res. J. 4, 27-46.

Situmorang, R. O. P, Barus, S. P., 2015. Mangrove Management as Source of Food Alternative by the Women Fishermen Group in Sei Nagalawan, North Sumatra, Indonesia. Presented at the The International Conference of Indonesia Forestry Researchers III, Bogor.

Susilo, H., Takahashi, Y., Yabe, M., 2017. The opportunity cost of labor for valuing mangrove restoration in Mahakam Delta, Indonesia. Sustain. Switz. 9, 1-13.

Tsuji, K., Sebastian, L. S., Ghazalli, M. N. F., Ariffin, Z., Nordin, M. S., Khaidizar, M. I., Dulloo, M. E., 2011. Biological and ethnobotanical characteristics of Nipa Palm (Nypa fructicans wurmb.): A review. Sains Malays. 40, 1407-1412.

Wahyuni, Y., Putri, E. I. K., Simanjuntak, S., 2014. Valuasi total ekonomi hutan mangrove di kawasan Delta Mahakam, Kabupaten Kutai Kartanegara, Kalimantan Timur. J. Penelit. Kehutan. Wallacea 3, 1-12.

Wang, P., Numbere, A. O., Camilo, G. R., 2016. Long-term changes in mangrove landscape of 
the niger river delta, Nigeria. Am. J. Environ.

Sci. 12, 248-259.

Zain, Z., Hutabarat, S., Prayitno, B., 2014. Potency of Mahakam Delta in East Kalimantan. Int. J. Sci. Eng. 6, 126-130.

Zakaria, R. M., Aslezaeim, N., Sofawi, A. B., 2017. Effects of water properties and soil texture on the growth of a mangrove palm; Nypa fruticans on carey Island, Malaysia.

Pak. J. Bot. 49, 33-39. 
Available on line at:

ISSN: 2354-5844 (Print)

http://ijwem.ulm.ac.id/index.php/ijwem

ISSN: 2477-5223 (Online)

Journal of Wetlands Environmental Management

Vol 7, No 1 (2019) 50 - 59

http://dx.doi.org/10.20527/jwem.v7.v1.193

-----Accredited by Directorate General of Higher Education Indonesia, No. 21/E/KPT/2018, Valid until 9 July 2023 ----- 